\title{
THE ANALYSIS OF COMPUTER SYSTEMS DEDICATED FOR THE ASSESSMENT OF FLIGHT SAFETY
}

\section{ANALIZA SYSTEMÓW INFORMATYCZNYCH SŁUŻĄCYCH DO OCENY BEZPIECZEŃSTWA LOTÓW STATKÓW POWIETRZNYCH}

\author{
Mirosław Zieja \\ Air Force Institute of Technology \\ Instytut Techniczny Wojsk Lotniczych \\ 01-494 Warszawa, ul. Księcia Bolesława 6 \\ e-mail: miro@itwl.pl
}

\begin{abstract}
The paper has been intended to present the analysis of computer systems used for the assessment of flight safety of aircraft operated by the aviation of the armed forces of the Republic of Poland. Data collected in these systems allow of analyses of air events that have occurred in the aviation of the armed forces of the Republic of Poland. What has been presented in the paper are exemplary statistical statements generated by the system 'TURAWA' intended for the analyses and assessment of flight safety level in the aviation of the armed forces of the Republic of Poland. Further capabilities of developing this system have also been shown.
\end{abstract}

Keywords: aircraft, pilot, safety, reliability, TURAWA, AWAR

Streszczenie: W niniejszym artykule została przedstawiona analiza systemów informatycznych służących do oceny bezpieczeństwa lotów statków powietrznych eksploatowanych w lotnictwie Sił Zbrojnych RP: „AWAR”, „TURAWA”. Dane zgromadzone $\mathrm{w}$ tych systemach pozwalają na dokonywanie analiz dotyczących zdarzeń lotniczych zaistniałych w lotnictwie Sił Zbrojnych RP. W artykule przedstawiono przykładowe zestawienia statystyczne generowane przez kompleksowy system analizy i oceny bezpieczeństwa lotów lotnictwa Sił zbrojnych RP „TURAWA” oraz wskazano dalsze obszary rozwoju tego systemu.

Slowa kluczowe: statek powietrzny, pilot, bezpieczeństwo, niezawodność, TURAWA, AWAR. 


\section{THE ANALYSIS OF COMPUTER SYSTEMS DEDICATED FOR THE ASSESSMENT OF FLIGHT SAFETY}

\section{Introduction}

Gathering information on air events, analysing them, drawing conclusions and forwarding suggestions, and supervising any preventive actions to make them effective - all these steps compose one of the most essential areas of activity of the flight-safety service.

The systematic gathering of information on air events as well as using it reasonably to diagnose and forecast the flight safety level have been aimed at finding some vital lines for preventive activity. This information enables determination of areas hazardous to flight safety, resulting from many and various deficiencies in the human being's actions, the unreliability of aeronautical systems, the complexity of air missions, errors in the airtraining organisation and not sufficient safeguards against any risks and hazards as well as adverse environmental effects. This knowledge allows, in turn, of the risk assessment and reasonable decision-making on any preventive measures/actions.

Information on the accident rate, available at any organisational level of the flight-safety service, is predominantly sourced from the following:

- reports on air events,

- telegrams/cablegrams; orders/dispositions/instructions,

- monthly statements of air events that have occurred in air bases,

- analyses of flight safety level,

- databases on air events,

- analyses of aircraft reliability;

- bulletins issued by Instytut Techniczny Wojsk Lotniczych (Air Force Institute of Technology) and by Laboratorium Kontroli Sprzętu Lotniczego (Laboratory for Aeronautical Systems Monitoring),

- national and foreign publications.

Data used for the flight-safety analysis and assessment can be found in the time studies and reports issued by air accident investigation boards. The correct and timely accomplishment of any actions to prevent air accidents requires a lot of calculations, often laborious. In particular, it refers to the statistics of failure rates in aviation as well as periodical analyses and reports. To relieve the officers of the Flight-Safety Staff at the Air Force Command (Szefostwo BL DSP) of this kind of work and to enable them to 
focus upon analytical and conceptual work, computers have been widely introduced. In 1995 the AWAR system was introduced, i.e. a system intended to analyse factors that determine causes of air events. This gave grounds for taking any preventive actions.

\section{The AWAR system}

The computer-based system AWAR has been intended to collect and process any information on:

- air accidents,

- prerequisites for air accidents.

The primary users of the system are the Flight Safety Staff at the Air Force Command. The AWAR system is operated using a local IBM PC at the Air Force Command. It does not require any specification of the computer since it operates under the DOS console. AWAR is not a network system. Therefore, it is unable to perform the actual monitoring of the flight safety level. The loading of collected data is considerably delayed, since air bases have no immediate access to the system.

What is recorded in the AWAR system are all air events, i.e. air incidents and accidents, crashes included. The records comprise what follows: the class, location, and course of the event, the description of weather conditions, and collective data on the aircrew on the very day of the event. Basing on the recorded data, the AWAR system allows of generating collective statistical statements on air events in a given time interval. However, the system lacks thorough data on the aircrew, aircraft, and preventive actions.

Since the scope of collected data is rather narrow and there is no logical coherence among data on the flying staff, flights, aircraft, air events, and preventive actions, the AWAR system does not allow of identifying weak points in the systems of air training, flight organisation and aircraft operation, which all together prove deciding to the safety of flights flown on different aircraft types. Nevertheless, the system has proved there is a capability to apply computer systems to evaluate flight safety level.

\section{The TURAWA system}

The above-mentioned reasons have proved good enough for constructing a complex system of flight-safety analysis and assessment. The system labelled 'TURAWA' has been intended for the aviation of the armed forces of the Republic of Poland. Works on this system were started at ITWL in 2003. Implementation of the system into the operational use is expected in 2008, after some period of experimental use. 


\subsection{Configuration of the TURAWA system}

The TURAWA system keeps functioning within a computer network. It has been designed using a three-layer architecture (Fig. 1).The following components are to be distinguished:

- the client layer that comprises computers of the end users of the system, each computer being furnished with the web browser (WWW),

- the application layer, i.e. the server with the logic of the system,

- the database layer, i.e. database server where recorded data are located.

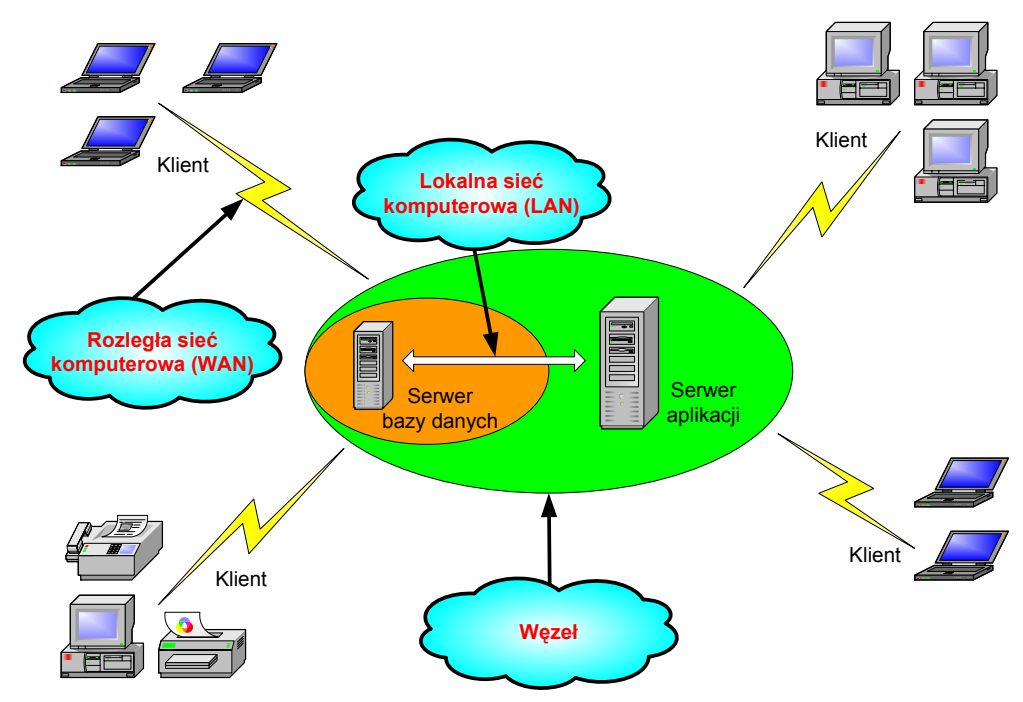

Fig. 1. The three-layer architecture of the TURAWA system

Any user of the system connects to the application server, which transfers the received request to the database server. The database server processes the request, i.e. finds the requested data and returns it back to the application server which in turn serves it back to the web browser client (system user). The data collecting and processing take place in the Oracle10g-grounded database. The application and database servers, interconnected with the Local Area Network (LAN), make up the so-called system node to be located at ITWL. ITWL has been assumed to perform the function of the system administrator.

\subsection{The scope of information collected in the TURAWA system}

Any analyses offered by the TURAWA system are based on the collection of data gathered in the system. The collection of data can be divided into five major sets: 
- flying staff: recorded is data on every member of the flying staff, including their personal data, the military-service records, education (civilian and military), command of foreign languages, specialist's class/rank, the level of skill and instruction gained, qualifications/competence, instances of the unfitness for service, health, stays at hospitals, sanatoria, and on leave, other;

- air events: recorded are all air events, i.e. air incidents and accidents, crashes; the data includes: the class, location, and course of the event, the description of weather conditions, data on the aircrew, data on aircraft, expert opinions issued by the Air Accident Investigation Board, causes of the event, deficiencies, other;

- flights: recorded is each flight of an aircarft, inluding: the day/hour of take-off, the total flying time, times of flying in particular weather conditions, the kind of flight, information on exercises and inspections accomplished during the flight, information on all aircrew members: their on-board functions and times of flying in a shaded cockpit;

- aircraft: the most essential data on the aircraft itself and operational use thereof (refers to each aircraft participating in a given air event) - this data is acquired from the SAMANTA BIS system;

- preventive actions: data on preventive actions undertaken as the result of investigating into every air event as well as data on preventive treatment issued by the flight-safety service on the grounds of problem analyses of a set of air events; the following data are recorded: the cause of introducing preventive measure(s), the document (its name and number) that demands this preventive measure(s) to be introduced, the drawer of the document, the date of issue of the document, the kind and substance of the preventive measure(s)/action(s), recipients of the recommendation(s), the time-limit for introducing the preventive measures, the date of completing the task.

\subsection{Analysis and evaluation of the flight safety}

What the TURAWA system allows of is, in particular, what follows:

- analysis and qualitative assessment of the safety of flight flown on different aircraft types, over any time interval, and at any organisational level of the military aviation; also, flight-safety forecasts for any calendar-based time interval, and trends in this area, including the nature of the forecasted changes, the causes and effects thereof (e.g. Fig. 2); 


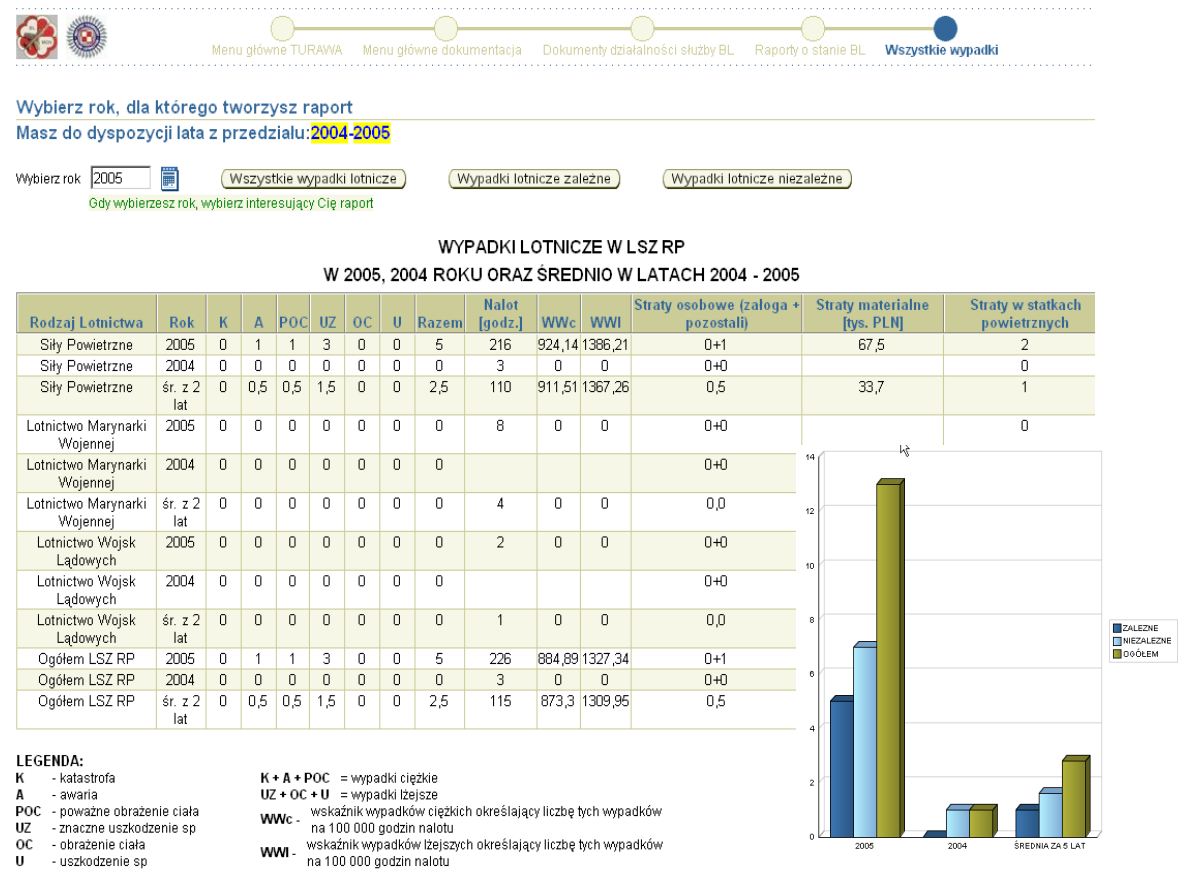

Fig. 2. The qualitative assessment of flight safety as found in the TURAWA system

- verification of training, organisational, operational undertakings aimed at maintaining the required flight-safety level;

- detailed identification and evaluation of environment-produced hazards to flight safety (birds, icing, etc,);

- support of decision-making processes in the field of flight safety, and of research/testing work intended to find causes of particular effects; also, identification of interrelationships between causes and effects of undesirable air events;

- design, implementation, and monitoring of the process of executing the recommended preventive measures/actions, evaluation of the effectiveness thereof;

- installation or generation of libraries of data on air rules \& regulations, aviation law, the essential aircraft and aiborne equipment specifications; other data suggested by system users;

- identification of weak points in the systems of air training, flight organisation and aircraft operation, which all together prove deciding to the safety of flights flown on different aircraft types;

- comparison of safety levels of flights flown by military aviations of NATO member countries; 


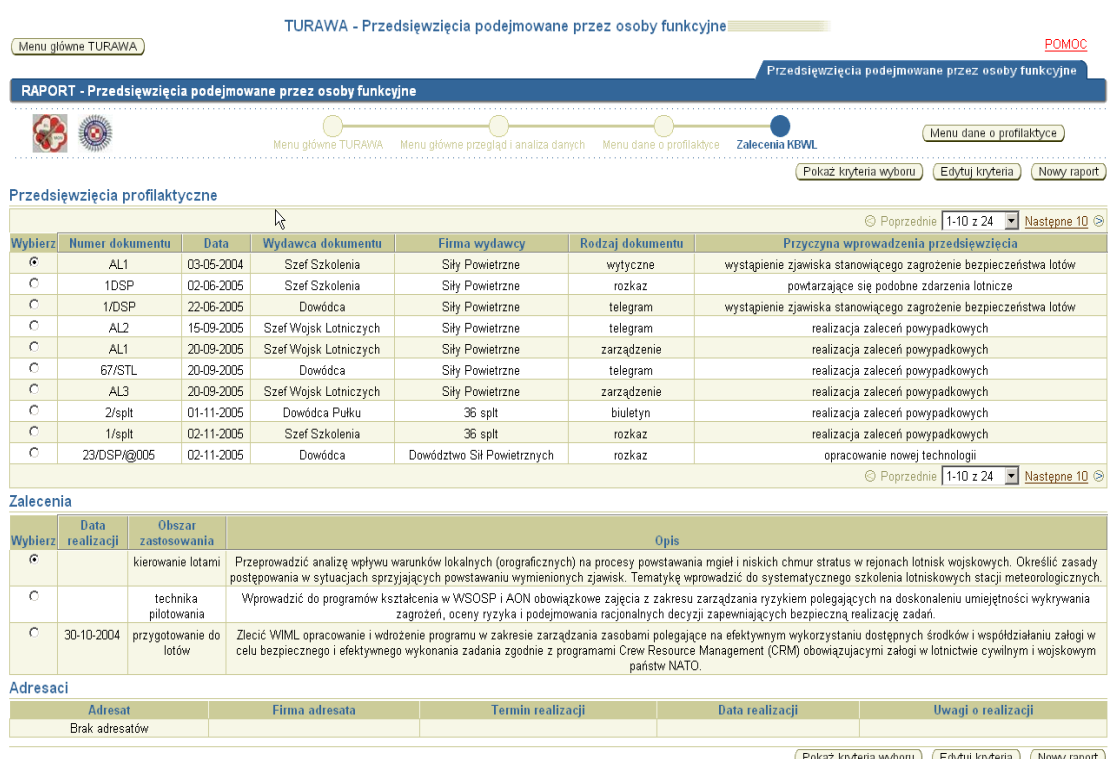

Fig. 3. The TURAWA system's records on preventive measures

- the actual assessment of, e.g. the skill(s) gained, according to some preset criteria, health, etc., of any group of the flying staff (an individual pilot, an aircrew, specified groups of pilots, the whole flying staff of the military aviation of the Republic of Poland) (Fig. 4),

and some other kinds of examining the flight safety of aircraft operated by the military aviation.

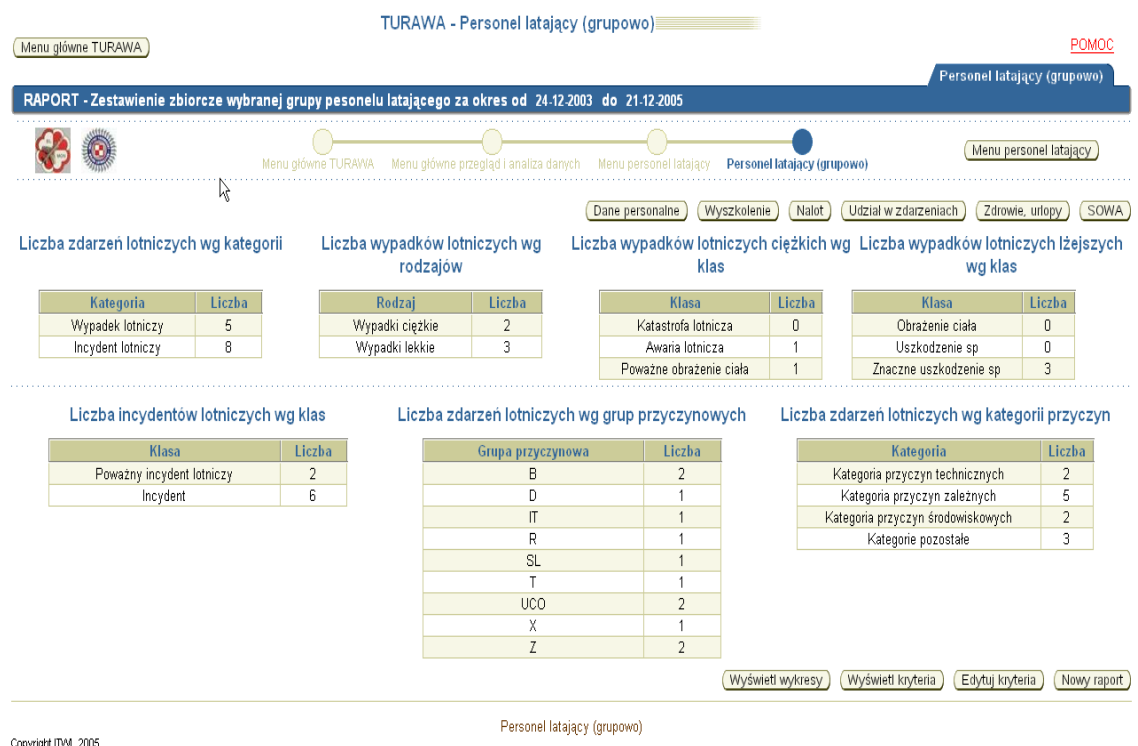

Fig. 4. The assessment of the flying staff's skill and instruction 


\section{Math methods of the flight-safety assessment in the TURAWA system}

The flight-safety assessment in the computer-based TURAWA system has been grounded on statistical relative and absolute criteria. The system allows of determining the flight-safety rates for any operational-use period selected by the user.

The flight-safety assessment in the TURAWA system is based on the following absolute statistical rates:

- the total number of air accidents in a given time interval,

- the number of air crashes,

- the number of failures/damages,

- the number of defects,

- the number of persons killed in air crashes.

The partial rates of the flight-safety assessment, used in the TURAWA system, include:

- the number of air accidents due to ANY factor,

- the number of air accidents at the $i$-th stage of flight.

The flight-safety level as approached in the TURAWA system is determined statistically, also on the grounds of the following, relative, safety rates:

- average flying time of aircraft per one air accident:

$T_{w}=\frac{T}{n_{w}}$

- average flying time of aircraft per one air crash:

$T_{k}=\frac{T}{n_{k}}$

- average flying time of aircraft per one air incident:

$T_{i n}=\frac{T}{n_{\text {in }}}$

where:

$n_{w}, n_{k}, n_{i n}$ - numbers of air accidents, crashes, incidents - respectively - in the total flying time.

The qualitative flight-safety analysis of flight safety, carried out by the TURAWA system, is featured with what follows:

- it allows of only general assessment of the flight-safety level;

- it does not take any account of the effective work of the 'pilot-aircraft' system;

- it evaluates the flight-safety level after an air event has occurred; 
- it cannot be used to solve problems of flight-safety optimisation with acount taken of the economic effectiveness.

Since there are some limitations of inferring methods used up to the present in the TURAWA system, there arises a need to apply also other predictive models to assess the flight safety, e.g.:

- probabilistic criteria of flight-safety assessment,

- simulation methods of flight-safety assessment,

- artificial intelligence.

\section{Conclusion}

The in the TURAWA system applied complex approach to the problem of flight safety allows of rational flight-safety control. It is possible owing to the actual monitoring of the occurring air events, the causes and effects thereof, evaluation of the level of skill and instruction of the flying staff, and the assessment of how the preventive actions have been completed.

Application of the most recent solutions in the field of designing databases has allowed of providing the open-loop system. Implementation of the three-layer architecture (application server, database server, client) has enabled further development of the system (e.g. extending the scope of its functioning to include other components of the air training) and offers capabilities to cooperate with other systems (e.g. with the SAN system, i.e. the system to analyse and evaluate the reliability of the military aircraft).

Nowadays, of great significance is the problem of how to rationally use all the information collected in both the systems, i.e. AWAR and TURAWA. Therefore, formulation of mathematical models that enable qualitative and quantitative analyses of the collected data. Application of suitable mathematical models in the inferring process is expected to allow of more complex and thorough assessment of the flight-safety level.

\section{Bibliography}

1. Tomaszek H., Wróblewski M.: Podstawy oceny efektywności eksploatacji systemów uzbrojenia lotniczego. Bellona, Warszawa 2001.

2. Borgoń J., Jaźwiński J., Klimaszewski S., Żmudziński Z., Żurek J.: Symulacyjne metody badania bezpieczeństwa lotów. ASKON, Warszawa 1998. 


\section{ANALIZA SYSTEMÓW INFORMATYCZNYCH SŁUŻĄCYCH DO OCENY BEZPIECZEŃSTWA LOTÓW STATKÓW POWIETRZNYCH}

\section{Wprowadzenie}

Zbieranie informacji o zdarzeniach lotniczych, ich analizowanie, opracowywanie wniosków i propozycji oraz nadzorowanie przedsięwzięć profilaktycznych $\mathrm{w}$ aspekcie ich skuteczności jest jednym z podstawowych obszarów działania służby bezpieczeństwa lotów.

Systematyczne zbieranie informacji dotyczących zdarzeń lotniczych, ich racjonalne wykorzystanie do diagnozowania i prognozowania stanu bezpieczeństwa lotów ma na celu wytyczenie zasadniczych kierunków działalności profilaktycznej. Informacje te pozwalają na ustalenie obszarów zagrożeń bezpieczeństwa lotów, wynikających z niedoskonałości działania człowieka, zawodności techniki lotniczej, złożoności zadań lotniczych, błędów $\mathrm{w}$ organizacji i zabezpieczeniu szkolenia lotniczego oraz z negatywnego wpływu środowiska. Umożliwia to prowadzenie oceny ryzyka i podejmowanie racjonalnych działań profilaktycznych.

Podstawowymi źródłami informacji o wypadkowości lotniczej na każdym szczeblu służby bezpieczeństwa lotów są:

- protokoły badań zdarzeń lotniczych;

- telegramy i zarządzenia;

- miesięczne zestawienia zdarzeń lotniczych, zaistniałych w jednostkach lotniczych;

- analizy stanu bezpieczeństwa lotów;

- bazy danych o zdarzeniach lotniczych;

- analizy niezawodności statków powietrznych oraz biuletyny informacyjne opracowywane przez Instytut Techniczny Wojsk Lotniczych i Laboratorium Kontroli Sprzętu Lotniczego;

- publikacje krajowe i zagraniczne.

Dane służące do analizy i oceny bezpieczeństwa lotów zawarte są w chronometrażu i protokółach wydawanych przez komisje badające zdarzenia. Poprawne i terminowe wykonanie działań profilaktycznych zapobiegających wypadkom lotniczym wymagało dużej ilości, często żmudnych obliczeń. Dotyczyło to w szczególności prowadzenia statystyki awaryjności lotniczej oraz wykonania okresowych analiz i sprawozdań. Odciążenie oficerów Szefostwa BL DSP od tego typu prac i umożliwienie 
im skoncentrowania uwagi na pracach analityczno-koncepcyjnych zostało osiągnięte poprzez wykorzystanie komputerów. W 1995 roku wdrożono system analizy czynników determinujących przyczyny zdarzeń lotniczych stanowiących podstawę do działań profilaktycznych „AWAR”.

\section{System ,AWAR"}

System informatyczny „AWAR” przeznaczony jest do gromadzenia i przetwarzania informacji dotyczących:

- wypadków lotniczych;

- przesłanek wypadków lotniczych.

Głównym użytkownikiem systemu jest Szefostwo Bezpieczeństwa Lotów DSP. System „AWAR” jest systemem pracującym na lokalnym komputerze klasy IBM PC w DSP. Nie wymaga on szczególnej specyfikacji komputera, gdyż działa pod konsolą DOS-ową. Ze względu, iż system „AWAR” nie jest systemem sieciowym, nie jest on $\mathrm{w}$ stanie śledzić na bieżąco poziomu bezpieczeństwa lotów. Dane gromadzone w tym systemie wprowadzane są z dużym opóźnieniem, gdyż jednostki lotnicze nie mają do niego bezpośredniego dostępu.

W systemie „AWAR” rejestrowane są wszystkie zdarzenia lotnicze od incydentu do katastrofy lotniczej, w tym: klasa zdarzenia, miejsce, okoliczności i przebieg zdarzenia, opis warunków atmosferycznych, zbiorcze dane o załodze na dzień zdarzenia lotniczego. Na podstawie rejestrowanych danych system „AWAR” umożliwia zbiorcze zestawienia statystyczne zdarzeń lotniczych za określony przedział czasu. W systemie jest jednak brak kompleksowych danych dotyczących personelu latającego, statków powietrznych oraz przedsięwzięć profilaktycznych.

Ze względu na wąski zakres gromadzonych danych oraz brak zachowania spójności logicznej między danymi dotyczącymi personelu latającego, lotów, statków powietrznych, zdarzeń lotniczych oraz profilaktyką system „AWAR" nie umożliwia wykrywania słabych ogniw w systemie szkolenia lotniczego, organizacji lotów oraz eksploatacji statków powietrznych, decydujących o poziomie bezpieczeństwa lotów na różnych typach statków powietrznych. Nie mniej jednak system ten wskazał możliwość zastosowania systemów informatycznych do oceny bezpieczeństwa lotów.

\section{System ,TURAWA"}

Powyższe względy legły u podstaw budowy dla lotnictwa SZ RP kompleksowego systemu analizy i oceny bezpieczeństwa lotów, który funkcjonował będzie pod kryptonimem „TURAWA”. Prace nad tym 
systemem zostały podjęte przez ITWL w 2003 roku. Przewiduje się, że jego wdrożenie do eksploatacji użytkowej nastapi w 2008 roku, po przeprowadzeniu eksploatacji próbnej.

\subsection{Konfiguracja systemu „TURAWA”}

System „TURAWA” funkcjonuje w sieci komputerowej. Zaprojektowano go wg architektury trójwarstwowej (rys. 1), w której wyróżnić można:

- warstwę klienta obejmującą komputery użytkownika systemu, z których każdy wyposażony jest w przeglądarkę stron (WWW),

- warstwę aplikacji, którą stanowi serwer zawierający logikę systemu,

- warstwę bazy danych, realizowaną za pomocą serwera bazy danych przechowującego zarejestrowane dane.

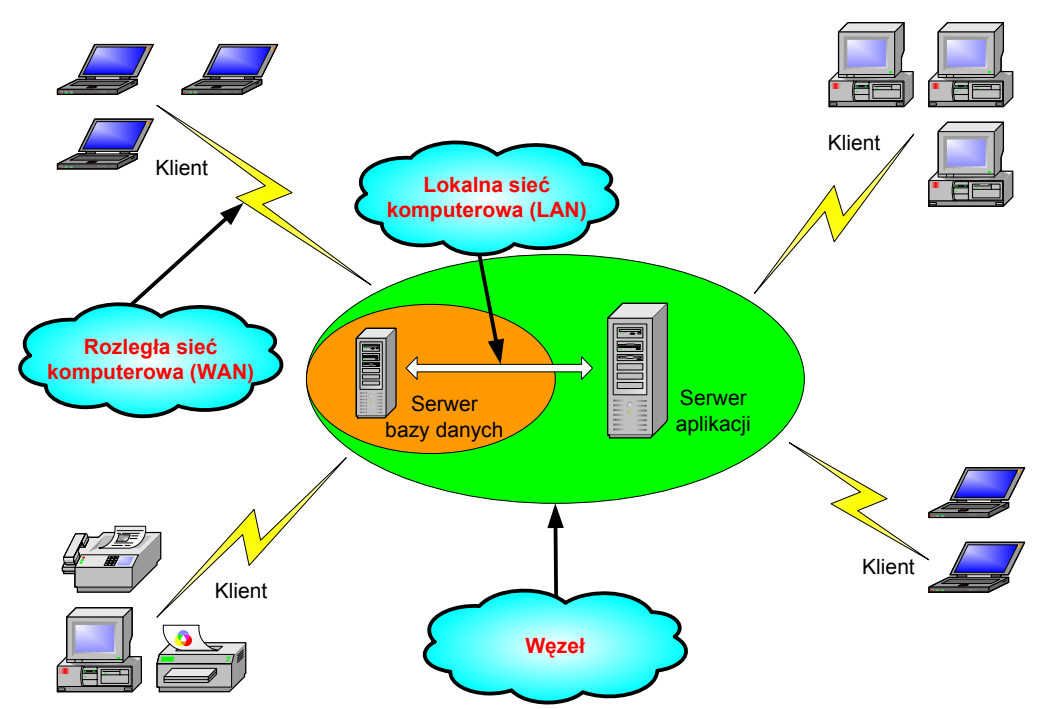

Rys. 1. Schemat architektury trójwarstwowej systemu „TURAWA”

Użytkownik systemu łączy się $\mathrm{z}$ serwerem aplikacji, który przesyła odebrane żądanie do serwera bazy danych. Serwer bazy danych realizuje odpowiedź na otrzymane zapytanie i zwrotnie, przez serwer aplikacji, odsyła ją do użytkownika systemu. Gromadzenie i przetwarzanie informacji odbywa się w bazie danych opartej na Oracle10g. Serwery aplikacji i bazy danych, połączone między sobą lokalną siecią komputerową, stanowią tzw. węzeł systemu, który umiejscowiony będzie w ITWL. Zakłada się, że Instytut będzie pełnił funkcję administratora systemu. 


\subsection{Zakres informacji gromadzonej w systemie „TURAWA”}

Podstawą wszelkich analiz, które umożliwia system „TURAWA” są gromadzone w nim informacje. Podzielić je można na pięć zasadniczych zbiorów:

- personel latający: rejestrowane są dane o każdym członku personelu latającego,

w tym: podstawowe dane ewidencyjne, przebieg służby wojskowej, wykształcenie cywilne i wojskowe, znajomość języków obcych, klasa specjalisty, poziom wyszkolenia, uprawnienia, niezdolności do służby, stan zdrowia, pobyty w szpitalach, sanatoriach, urlopy i inne);

- zdarzenia lotnicze: rejestrowane są wszystkie zdarzenia lotnicze od incydentu do katastrofy lotniczej, w tym: klasa zdarzenia, miejsce, okoliczności i przebieg zdarzenia, opis warunków atmosferycznych, dane o załodze, dane o statku powietrznym, ekspertyzy komisji, przyczyny zdarzenia, niedociągnięcia, i inne;

- loty: rejestrowany jest każdy lot statku powietrznego, w tym: data i godzina startu, ogólny czas lotu, czasy lotu w poszczególnych warunkach atmosferycznych, rodzaj lotu, informacje o wykonywanych w locie ćwiczeniach, kontrolach oraz o wszystkich członkach załogi: funkcja na pokładzie i czas lotu w zasłoniętej kabinie;

- statek powietrzny: podstawowe dane ewidencyjno-eksploatacyjne każdego statku powietrznego uczestniczącego w zdarzeniu lotniczym (dane te pozyskiwane są z systemu SAMANTA BIS);

- profilaktyka: dane o przedsięwzięciach profilaktycznych podejmowanych $\mathrm{w}$ wyniku badań każdego zdarzenia lotniczego, jak również o zaleceniach profilaktycznych wydawanych przez służbę bezpieczeństwa lotów na podstawie analiz problemowych zbioru zdarzeń lotniczych; rejestrowane są takie dane jak: przyczyna wprowadzenia profilaktyki, nazwa, i nr dokumentu nakazującego jej wprowadzenie, nazwa wydawcy dokumentu, data wydania dokumentu, rodzaj i treść przedsięwzięcia profilaktycznego, adresaci zalecenia, termin realizacji oraz data wykonania.

\subsection{Analiza i ocena bezpieczeństwa lotów}

W szczególności „TURAWA” umożliwia:

- analizę i ocenę jakościową stanu bezpieczeństwa lotów na różnych typach statków powietrznych, za dowolny przedział czasu i na dowolnym szczeblu organizacyjnym lotnictwa jak również prognozę stanu bezpieczeństwa lotów na określony horyzont czasu 
kalendarzowego, oraz określenie tendencji i charakteru zachodzących zmian, ich przyczyn i skutków, jakie mogą przynieść (np. rys. 2);

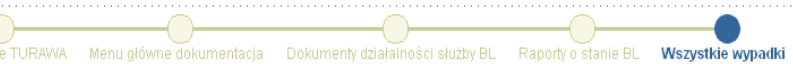

Wybierz rok, dla którego tworzysz raport

Masz do dyspozycji lata z przedzialu:2004-2005

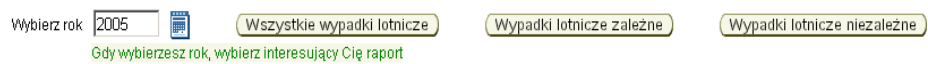

WYPADKI LOTNICZE WLSZRP

W 2005, 2004 ROKU ORAZ ŚREDNIO W LATACH 2004 - 2005

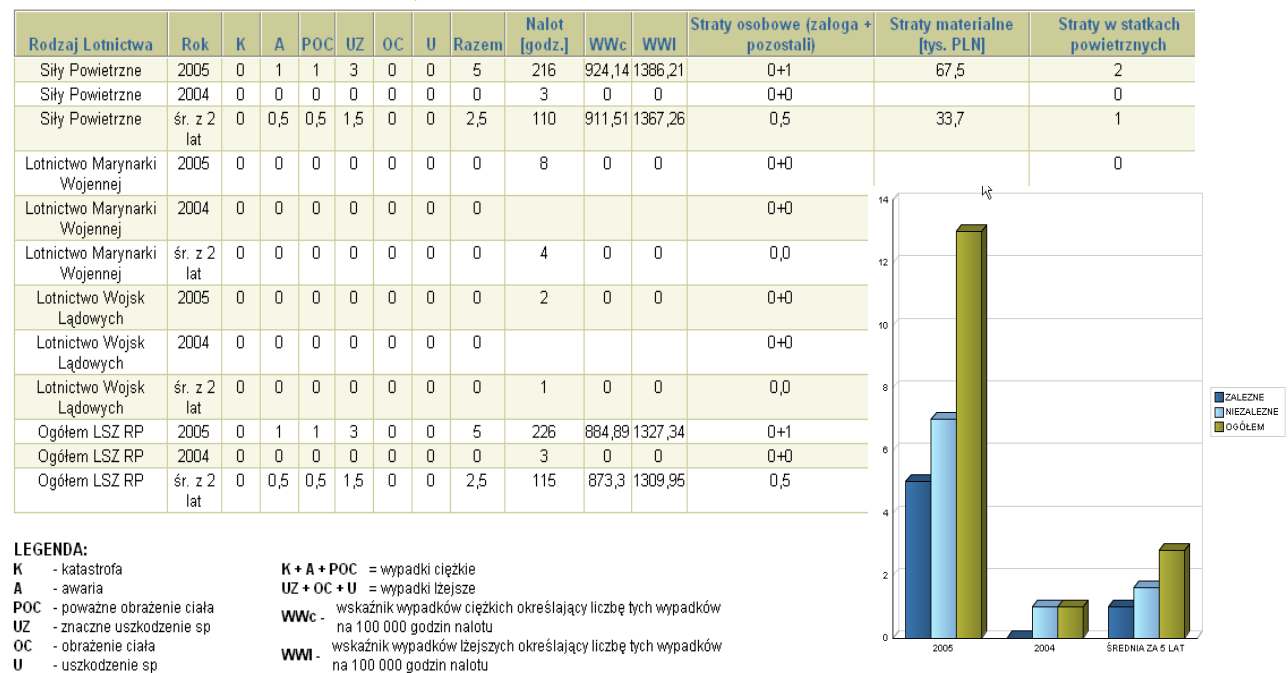

Rys. 2. Ocena jakościowa stanu bezpieczeństwa lotów w systemie TURAWA

- weryfikację przedsięwzięć szkoleniowych, organizacyjnych i eksploatacyjnych, ukierunkowanych na utrzymanie wymaganego poziomu bezpieczeństwa lotów;

- szczegółową identyfikację i ocenę zagrożeń bezpieczeństwa lotów ze strony środowiska (ptaków, oblodzeń, itp.);

- wspomaganie procesów decyzyjnych $\mathrm{w}$ dziedzinie bezpieczeństwa lotów oraz badań związanych $\mathrm{z}$ ustalaniem przyczyn określonych skutków jak też wykrywanie zależności zachodzących między przyczynami i skutkami niepożądanych zdarzeń lotniczych;

- projektowanie, wdrażanie oraz śledzenie procesu realizacji zastosowanych przedsięwzięć profilaktycznych jak i ocenę jej skuteczności (rys. 3);

- instalowanie lub tworzenie bibliotek danych dotyczących przepisów lotniczych, prawa lotniczego, podstawowych danych taktyczno- 
technicznych eksploatowanych statków powietrznych, ich wyposażenia oraz innych danych zaproponowanych przez użytkowników systemu;

- wykrywanie słabych ogniw w systemie szkolenia lotniczego, organizacji lotów oraz eksploatacji statków powietrznych, decydujących o poziomie bezpieczeństwa lotów na różnych typach statków powietrznych;

- porównywanie poziomu bezpieczeństwa lotów na wojskowych statkach powietrznych w państwach należących do NATO;

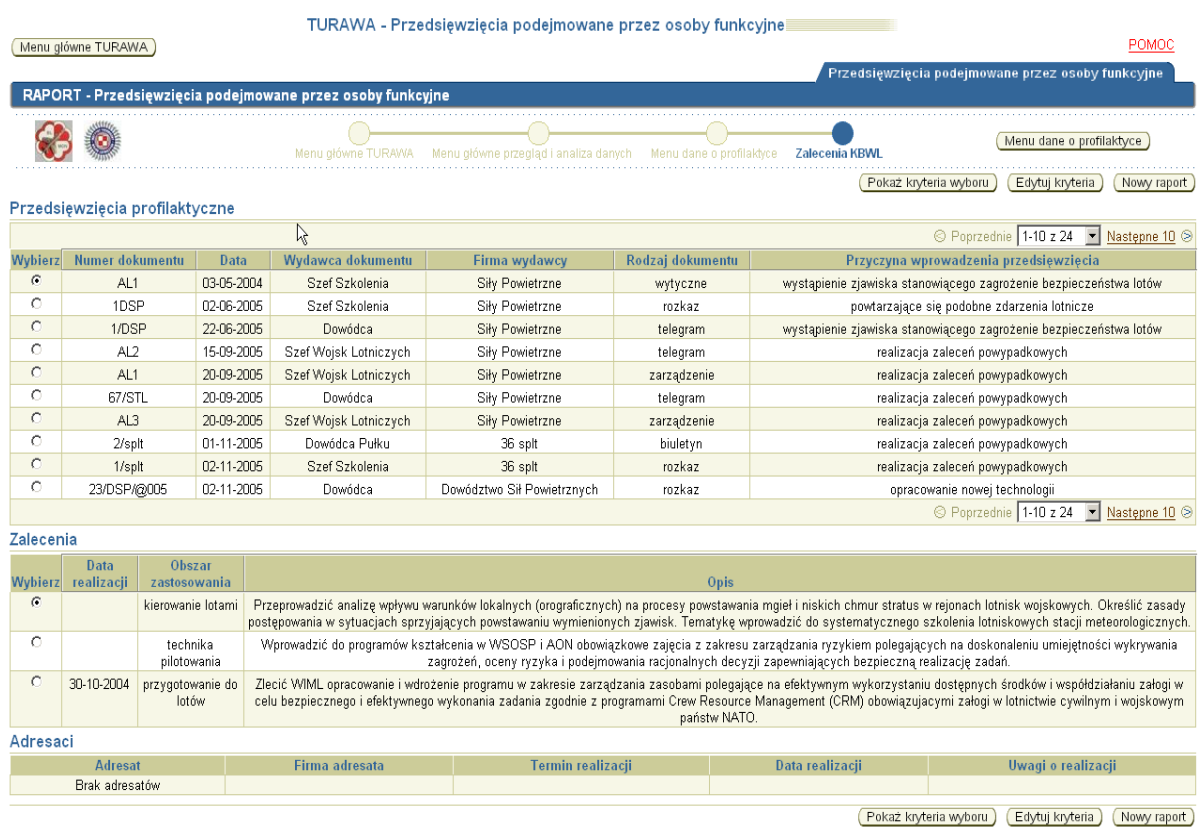

Rys. 3. Realizacja przedsięwzięć profilaktycznych rejestrowana w systemie TURAWA

- bieżącą ocenę (np. poziomu wyszkolenia wg zadanych kryteriów, stanu zdrowia, ...) dowolnej grupy personelu latającego (pojedynczego pilota, załogi SP, określonych grup pilotów, całości personelu lotnictwa wojskowego RP) (rys.4).oraz inne badania bezpieczeństwa lotów statków powietrznych eksploatowanych w lotnictwie wojskowym. 


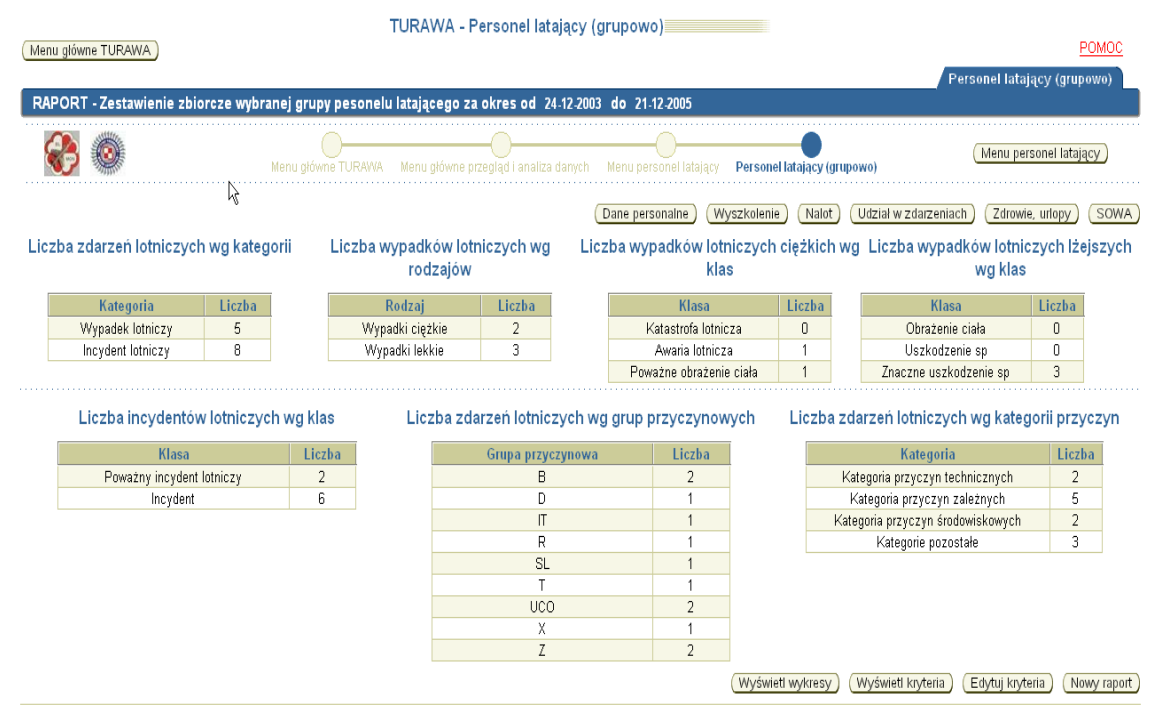

Rys. 4. Ocena poziomu wyszkolenia personelu latającego

\section{Matematyczne metody oceny bezpieczeństwa lotów w systemie "TURAWA"}

Ocena bezpieczeństwa lotów w systemie informatycznym „TURAWA” jest realizowana na podstawie względnych oraz bezwzględnych kryteriów statystycznych. System „TURAWA” pozwala na wyznaczenie wskaźników bezpieczeństwa lotów za dowolnie wybrany przez użytkownika okres eksploatacji.

Ocena bezpieczeństwa lotów w systemie „TURAWA” jest dokonywana na podstawie następujących bezwzględnych wskaźników statystycznych:

- ogólna liczba wypadków lotniczych za określony czas;

- liczba katastrof;

- liczba awarii;

- liczba uszkodzeń;

- liczba ofiar śmiertelnych w wyniku wypadków lotniczych.

Do cząstkowych wskaźników oceny bezpieczeństwa lotów wykorzystywanych w systemie „TURAWA należą:

- liczba wypadków lotniczych wywołanych dowolnym czynnikiem;

- liczba wypadków lotniczych na i-typ etapie lotu. 
Poziom bezpieczeństwa lotów w systemie „TURAWA” jest określany w ujęciu statystycznym również na podstawie następujących względnych wskaźników bezpieczeństwa:

- średni nalot statków powietrznych na jeden wypadek lotniczy:

$T_{w}=\frac{T}{n_{w}}$

- średni nalot na jedną katastrofę lotniczą:

$T_{k}=\frac{T}{n_{k}}$

- średni nalot na jeden incydent lotniczy:

$T_{i n}=\frac{T}{n_{\text {in }}}$

gdzie:

$n_{w}, n_{k}, n_{i n}$ - odpowiednio: liczby wypadków lotniczych, katastrof, incydentów w sumarycznym czasie nalotu.

Jakościowa analiza bezpieczeństwa lotów realizowana $\mathrm{W}$ systemie „TURAWA":

- umożliwia jedynie ogólną ocenę poziomu bezpieczeństwa lotów;

- nie uwzględnia użytecznej pracy lotniczego systemu ,pilot - SP”;

- ocenia poziom bezpieczeństwa po zaistnieniu wypadku lotniczego;

- nie może zostać wykorzystana do rozwiązywania zadań optymalizacji bezpieczeństwa lotów z uwzględnieniem efektywności ekonomicznej.

Ze względu na ograniczenia metod wnioskowania dotychczas wykorzystywanych w systemie „TURAWA" pojawia się potrzeba zastosowania również innych modeli predykcyjnych do oceny bezpieczeństwa lotów, np.:

- probabilistycznych kryteriów oceny bezpieczeństwa lotów,

- symulacyjnych metod oceny bezpieczeństwa lotów,

- sztucznej inteligencji.

\section{Wnioski}

Zastosowane w systemie TURAWA kompleksowe podejście do problemu bezpieczeństwa lotów pozwala na racjonalne sterowanie nim. Możliwe jest to poprzez bieżące śledzenie zachodzących zdarzeń lotniczych, ich przyczyn i skutków, ocenę poziomu wyszkolenia personelu latającego oraz ocenę realizacji podejmowanych działań profilaktycznych. 
Zastosowanie najnowszych rozwiązań z zakresu projektowania baz danych, pozwoliło na zapewnienie otwartości systemu. Implementacja trójwarstwowej architektury (serwer aplikacji, serwer bazy danych, klient) umożliwia dalszy rozwój systemu (np. rozszerzanie zakresu jego funkcjonowania na pozostałe elementy procesu szkolenia lotniczego), oraz daje możliwość współpracy z innymi systemami (np. z systemem analizy i oceny niezawodności wojskowych statków powietrznych „SAN”).

Obecnie niezwykle ważnym problemem jest konieczność racjonalnego wykorzystania informacji zgromadzonej $\mathrm{w}$ systemach informatycznych „AWAR” i „Turawa”. W tym celu szczególnie istotnym zagadnieniem jest opracowanie modeli matematycznych umożliwiających jakościową i ilościową analizę zgromadzonych danych. Zastosowanie odpowiednich modeli matematycznych $\mathrm{w}$ procesie wnioskowania umożliwi bardziej kompleksową i dokładną ocenę poziomu bezpieczeństwa lotów.

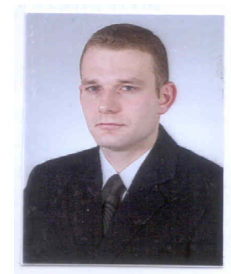

Mirosław Zieja, graduated from University of Lodz in 2004. M.Sc. in Mathematics specialized in Informatics. Since 2004 IT specialist in Air Force Institute of Technology. Participated in the development and implementation of the TURAWA system. 